\title{
Minimal scaling of the lophophore filter-pump in ectoprocts (Bryozoa) excludes physiological regulation of filtration rate to nutritional needs. Test of hypothesis
}

\author{
Hans Ulrik Riisgård ${ }^{1}$, Andrew Goldson ${ }^{2}$ \\ 'Institute of Biology, Odense University, Campusvej 55, DK-5230 Odense M, Denmark \\ ${ }^{2}$ School of Biological Sciences, University of Wales, Bangor, Gwynedd LL57 2UW, United Kingdom
}

\begin{abstract}
Feeding activity and growth in different ectoprocts (Electra pilosa, E. crustulenta, Celleporella hyalina) were related to naturally occurring algal concentrations in order to reveal if physiological regulation of the lophophore filter-pump to nutritional needs takes place. It was found that filter-feeding activity in E. pilosa and E. crustulenta is influenced by the concentration of algal cells in the surrounding water When the algal concentration becomes very low (corresponding to a few hundred Rhinomonas algal cells $\mathrm{ml}^{-1}$ ) the clearance rate of the ectoprocts is reduced due to a gradual shutting down of the number of actively feeding zooids. The zooids are inactive during starvation periods, but feeding is quickly resumed after a new addition of algal cells. Nearly $100 \%$ of the zooids are filter-feeding within a certain range of algal concentrations, corresponding to roughly 400 to 4000 Rhinomonas reticulata cells $\mathrm{ml}^{-1}$. The maximum individual zooldal clearance rate in $E$. pilosa was measured to be $0.28 \mathrm{ml} \mathrm{h}^{-1}$ zooid $^{-1}\left(18^{\circ} \mathrm{C}\right)$. Simultaneous clearance of 2 different sized algal cells in $E$. crustulenta showed that $R$. reticulata $(6 \mu \mathrm{m})$ and Tetraselmis sp. $(14 \mu \mathrm{m})$ are cleared from the water at approximately the same rate, whereas the removal of $4 \mu \mathrm{m}$ diameter Isochrysis galbana cells is approximately half this rate. The growth in colony size of $C$. hyalina and $E$. pilosa was exponential. The specific growth rate plotted as a function of algal concentration showed that the growth potential (about 10 to $12 \% \mathrm{~d}^{-1}$ I may be fully utilized at about 4000 Rhinomonas cells $\mathrm{ml}^{-1}$, corresponding to $5 \mu \mathrm{g}$ chlorophyll $a \mathrm{I}^{-1}$ This implies that ectoprocts in nature, as a rule, always utilize their clearance capacity and hence have no requirement for physiological regulation of the filter-pump
\end{abstract}

KEY WORDS: Filtration Clearance rate - Regulation of filter-pump - Retention efficiency · Food satiation. Specific growth rate Doubling time

\section{INTRODUCTION}

Suspension-feeding marine invertebrates must filter large volumes of water to meet their food requirements. The low concentrations of small suspended food particles in the sea are the key to understanding the characteristics of the filter-feeding. Presumably these characteristics evolved according to 'a principle of minimal scaling', whereby the dimensions of the filter-pumps are sufficient to enable continuous feeding at low rates, rather than discontinuous feeding at correspondingly high rate (Jørgensen 1975). This hypothesis appears to exclude physiological regulation of the filtration rate in response to nutritional needs. During recent years filter-feeding sponges, polychaetes, bivalves and ascidians have been characterized by analysis of the biological filter-pumps (Riisgård \& Larsen 1995). The studies have shown that lowenergy pumps continuously process the surrounding water through filters appropriately dimensioned for coping with the phytoplankton concentrations of the biotope. Thus, there is increasing evidence that filterfeeding in marine environments may be based on the principle of minimal scaling. However, most energetic studies on e.g. filter-feeding mussels are based on the assumption that the filtration rate is physiologically 
regulated in response to variations in the concentration of phytoplankton (Bayne et al. 1987, 1988, 1989, Hawkins \& Bayne 1992, Willows 1992, Sprung 1995; but see Jorgensen 1990, 1996, Riisgård 1991, Clausen \& Riisgard 1996). This raises the question of whether any benthic filter-feeders may have developed a physiological mechanism for regulation of the filter-pump to nutritional needs.

To further test the general validity of the above hypothesis for mimimal scaling in benthic invertebrate filter feeders we studied the influence of algal concentration on feeding and growth in ectoprocts.

Ectoprocts are colonial filter-feeding 'moss-animals' which may be regarded as the only group of true bryozoans (e.g. Ryland 1976, Hayward \& Ryland 1995; but see Nielsen 1987, 1995). More than 4000 living species of ectoprocts are known and an extensive fossil record of their 500 million yr history exists (McKinney 1990, Nielsen 1995). Zooids (autozooids) that are capable of feeding constitute the bulk of the ectoproct colony. When feeding, the zooids extend their lophophore, which consists of an inverted bell-shaped ring of ciliated tentacles, above the colony surface. Movement of lateral cilia on the tentacles produces a water current into the lophophore. During feeding, water containing suspended food particles, mainly phytoplankton, passes between the tentacles on its way out of the feeding apparatus (Ryland 1976). The particle capture mechanism has recently been studied in detail by Riisgård \& Manríquez (1997). Video recordings revealed that particles in the outgoing feeding-currents are stopped and stuck to the tentacles. Subsequently, the particles may move down the frontal surface of the tentacles towards the mouth, but more frequently another downwards transport mechanism is involved. By the action of tentacle flicking the adhering particles are conveyed back into the central current, created by the special lophophore pump-design, to be carried further downwards to the mouth at the bottom of the lophophore. The observations support the hypothesis of a laterofrontal filter, consisting of a row of stiff cilia each about $20 \mu \mathrm{m}$ long and spaced approximately $5 \mu \mathrm{m}$ apart (Gordon 1974), which mechanically strains the water. The central lophophore water together with a flicking action of the tentacles clean the filter and transport the particles towards the mouth.

A number of laboratory feeding and growth experiments have demonstrated the ability of ectoprocts to nourish themselves as true filter-feeders (Bullivant 1968a, b, Menon 1974, Winston 1976, Jebram \& Rummert 1978, Best \& Thorpe 1983, 1986, 1994, 1996, Gordon et al. 1987, McKinney 1990, Okamura 1992, Hunter \& Hughes 1993, 1995, Bayer et al. 1994, Bayer \& Todd 1996). Recently Risgård \& Manriquez (1997) quantified the zooidal water-processing rates in 15 species of actively feeding ectoprocts, but there is a general lack of information about the degree to which the filtration potential is actually being utilized in nature.

Hitherto, only a few attempts have been made to relate feeding activity and growth of ectoprocts to natural (low) algal concentrations. Bullivant (1968a) measured the clearance rate of the ctenostome Zoobotryon verticillatum at different algal concentrations to determine the 'satiation concentrations' with 4 species of algae. Above the satiation concentration it was found that the clearance rate decreased and it was assumed that the clearance rate declined in such a way that the ingestion rate became constant. A functional response of this type would imply that the filtration rate of ectoprocts is physiologically regulated.

In the present work we identify the range of algal concentrations within which ectoprocts exploit their clearance capacity. Feeding activity (i.e lophophore out) is related to the presence of algae in the surrounding water in order to interpret alterations in colony clearance rates as a response to both extremely low and unnaturally high algal concentrations. Further, we identify the lowest algal concentration that causes maximum growth rate of these ectoprocts in laboratory feeding experiments and compare this concentration with phytoplankton levels in nature in order to check if this implies that the clearance capacity is always utilized (i.e. no regulation of the filter-pump).

\section{MATERIALS AND METHODS}

Clearance rate capacity of Electra pilosa. All work on E. pilosa was performed at the School of Biological Sciences, University of Wales, Bangor, UK. The first goal was to measure the unlimited maximum clearance rate (i.e. the 'clearance capacity') of an individual zooid of E. pilosa in order to use this rate as a reference in subsequent experiments. Eight colonies of laboratory cultured E. pilosa, each growing on a rectangular piece of glass $(7.5 \times 3.9 \mathrm{~cm})$ and covering an area of 2.8 to $14.5 \mathrm{~cm}^{2}$, were fixed in a vertical position on the inner side of a glass vessel (height $6 \mathrm{~cm}$, diameter $11.7 \mathrm{~cm}$ ). The experimental vessel containing the colonies, as well as $550 \mathrm{ml}$ of filtered $(0.2 \mu \mathrm{m})$ seawater $(35 \% \mathrm{~S})$ and a magnetic stirrer, was placed on top of a combined temperature controlled plate $\left(18^{\circ} \mathrm{C}\right)$ /magnetic stirrer. Approximately 3500 Rhinomonas reticulata (formally Rhodomonas baltica; Novarino 1992) cells $\mathrm{ml}^{-1}$ were then added. Following an exposure period of about half an hour, the first measurements in a series of regular sampling was taken to determine the algal concentration. The reduction in the number of algal cells as a function of 
time was followed by taking samples $(15 \mathrm{ml})$ every 5 to $10 \mathrm{~min}$ and measuring the algal concentration with an electronic particle counter (Elzone model $80 \mathrm{xy}$ fitted with a $76 \mu \mathrm{m}$ orifice tube coincidence $<5 \%$ ). Following each measurement, the remaining water (about $13 \mathrm{ml}$ ) was immediately returned to the experimental beaker to ensure only an insignificant reduction in the total volume of water.

The clearance rate $(F)$ was determined from the exponential reduction in algal cell concentration using the formula:

$$
F=(V / n t) \ln \left(C_{0} / C_{l}\right)
$$

where $C_{0}$ and $C_{t}$ are the algal concentrations at time 0 and time $t$, respectively, $V=$ volume of water, and $n=$ number of ectoprocts counted under a stereo-microscope observed as the number of zooids containing algal pigment inside the gut (i.e. they had been actively feeding during the experiment). The exponential reduction in algal cell concentration was monitored and verified as a straight line in a semilog plot. The sedimentation rate of algal cells measured in controls without ectoproct colonies corresponded to $<5 \%$ of the clearance rate of the ectoprocts; corrections for sedimentation were therefore omitted.

Feeding-activity response to algal concentration. In order to study the feeding activity of Electra pilosa exposed to different initial microalgal (Rhinomonas reticulata) concentrations, the set-up described previously was modified. The magnetic stirrer was removed and strong mixing was instead generated by means of air-bubbling. Furthermore, one of the colonies was placed on the bottom of the vessel so that a certain area ( $27 \mathrm{~mm}^{2}$ ) of zooids could be observed (and counted) by means of a stereo-microscope. The zooids were starved overnight previous to an experiment. After adding an initial algal concentration to the experimental vessel, water samples for measurement of the algal concentration were taken every $5 \mathrm{~min}$, simultaneously with counting of the number of active zooids (i.e. lophophore out). The clearance rate was calculated for every 5 min interval using Eq. (1).

Feeding and particle retention in Electra crustulenta. E. crustulenta was collected on Fucus serratus in Kerteminde Fjord, Denmark, and clearance experiments were performed at $20 \% \mathrm{~S}$ and $20^{\circ} \mathrm{C}$ at the Fjord Biology Laboratory, Kerteminde, Denmark. Algal cells were added to a $100 \mathrm{ml}$ glass beaker containing strongly aerated seawater $(90 \mathrm{ml})$ and a colony of $E$. crustulenta growing on the surface of a fixed piece of F. serratus. Particle retention was examined by simultaneous measurement of the clearance of 2 flagellates with different sizes, either Rhinomonas reticulata (mean diameter $6 \mu \mathrm{m}$ ) and Tetraselmis sp. (14 $\mu \mathrm{m})$, or $R$. reticulata and Isochrysis galbana $(4 \mu \mathrm{m})$. The colony clearance rate between 2 algal additions was determined according to Eq. (1) using the equation of the regression line describing the exponential reduction in the algal cell concentration in a semilog plot.

Growth experiments. Clones of Celleporella hyalina and Electra pilosa were cultured on glass microscope slides $(39 \times 76 \mathrm{~mm})$ according to the methods of Hunter \& Hughes (1995) and Bayer et al. (1994), respectively. Once established, 4 separate clones, each of approximately 20 active zooids in number, were left on each slide. One slide from each of the 2 species was placed in a plastic rack, held in a $1 \mathrm{l}$ glass beaker containing $900 \mathrm{ml}$ of $0.2 \mu \mathrm{m}$ filtered seawater maintained at $18^{\circ} \mathrm{C}$ by means of a water bath. Airstones provided turbulent mixing and aeration of beakers. Algal cells (Rhinomonas reticulata) were added every $24 \mathrm{~h}$ to obtain a range of concentrations (between 800 and 18000 cells $\mathrm{ml}^{-1}$, see below). The number of cells in suspension was monitored twice daily (morning and evening) using a particle counter (Elzone $80 \mathrm{xy}$ ). Every third day the colonies were removed and hand drawn using a camera lucida. In addition, the total number of zooids was counted, noting the proportion of brown bodies as well as feeding and sexual zooids. The containers were cleaned and fresh filtered $(0.2 \mu \mathrm{m})$ seawater and algae were added following each set of observations. The experiment continued for a period of $12 \mathrm{~d}$. Five series (nos. 1 to 5) of feeding experiments with the 2 ectoproct species were performed. The mean $( \pm S D)$ algal concentrations used in each experiment were: no. 1 , $810 \pm 390 ;$ no. $2,2460 \pm 1320 ;$ no. $3,4620 \pm 2240 ;$ no. 4 ; $8830 \pm 3770$; no. $5,18500 \pm 6950$ cells $\mathrm{ml}^{-1}$.

The initial growth rate of small ectoproct colonies may be expected to be exponential, i.e. increase with a fixed percentage, $r$. Therefore, the growth rate of colony size $N$ (defined as either a function of total number of zooids or area of the colony) may be expressed by the equation:

or (by integration)

$$
\mathrm{d} N / \mathrm{d} t=r N
$$

or

$$
N=N_{0} \mathrm{e}^{r t}
$$

$$
\ln N=\ln N_{0}+t r
$$

where $N$ is the size of the colony at a given time $t$, and $N_{0}$ is the colony size at time $t=0$. Because $\ln N=$ $\log _{10} N / \log _{10} e$, Eq. (4) may also be written as: $\log _{10} N=$ $\log _{10} N_{0}+\operatorname{tr} \log _{10}$ e. A relation of this form gives a straight line if $t$ is plotted on the linear scale and $N$ on the logarithmic scale, the slope of the line is $r \log _{10} e$. In the present work the assumption of exponential growth is verified as a straight line when plotting the size of colony ( $N$, number of zooids or area of colony, $\mathrm{mm}^{2}$ ) against time $(t$, days) on semilogarithmic paper, and the value of $r$ is found by dividing the slope of the regression line with $\log _{10} \mathrm{e}=0.4343$. 

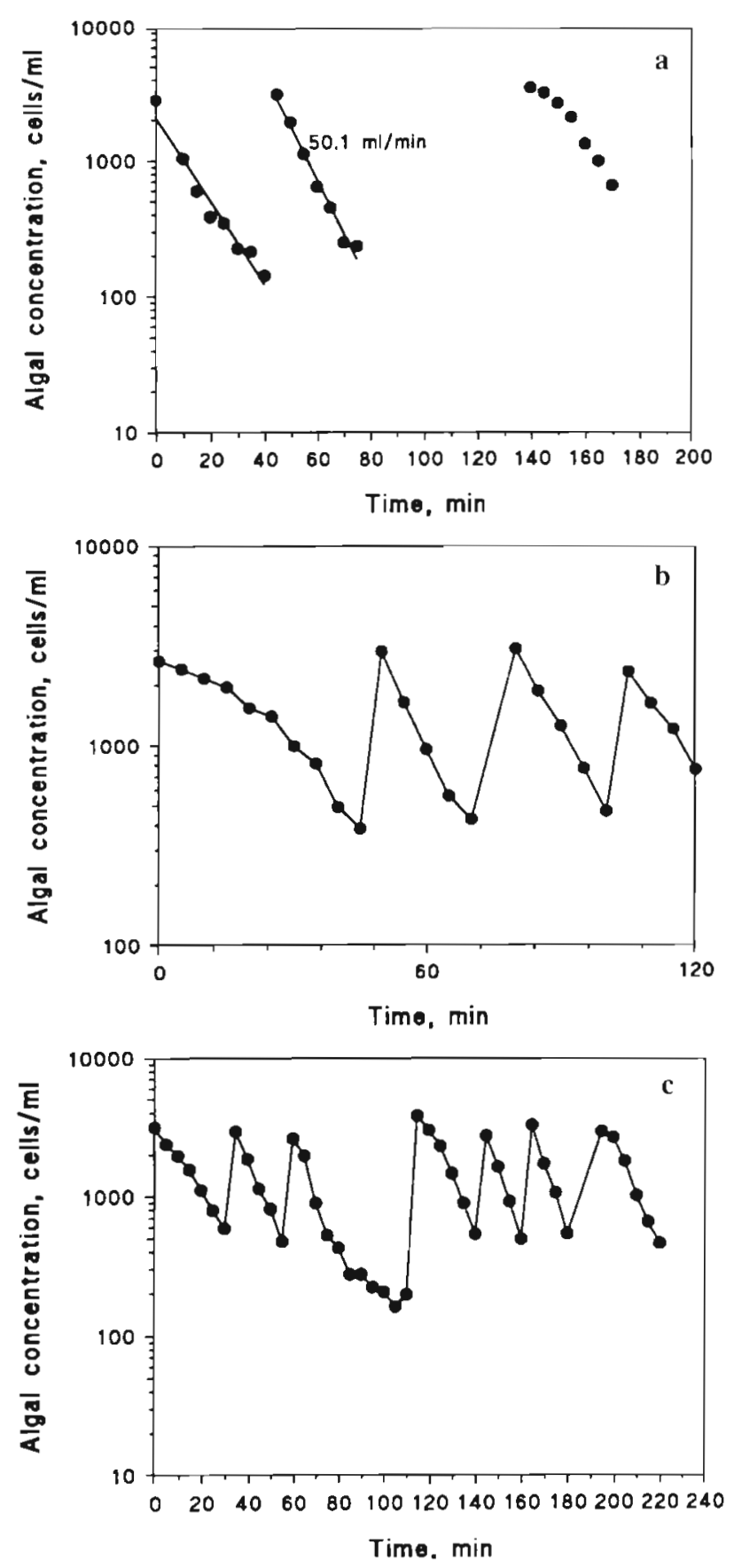

Fig. 1. Electra pilosa. Clearance of algal cells (Rhinomonas reticulata) in 3 experiments $(a, b, c)$ with E. pilosa colonies. The calculated clearance rate capacity of the colonies is shown in (a) along with the regression line for the exponential algal reduction following the second algal addition at time $45 \mathrm{~min}$. In all 3 cases it is seen that the initial clearance rate is relatively low, and further becomes reduced at low algal concentrations (see text for further information)

The doubling time for the colony $t_{2}$ is found by inserting $N=2 N_{0}$ in Eq. (3):

$$
t_{2}=\ln 2 / r=0.693 / r
$$

The constant $r$ has been designated as the 'intrinsic rate of natural increase' (Kitamura \& Hirayama 1984), or 'mean relative growth' (Bayer et al. 1994). In this work we use the more common expression 'specific growth rate' When only initial and final colony size are known the specific growth rate may be calculated as:

$$
r=\ln \left(N / N_{0}\right) / t
$$

\section{RESULTS}

\section{Clearance rate capacity and feeding activity response to algal concentration in Electra pilosa}

Fig. 1 shows a series of 3 experiments. The first experiment (Fig. 1a) shows 2 typical phenomena which were studied in more detail in the subsequent experiments: (1) the maximum colony clearance rate of $50.1 \mathrm{ml} \mathrm{min}^{-1}$ was first determined following an initial phase of lower clearance rate (i.e. the slope of regression line was smaller, the estimated clearance rate being $39.2 \mathrm{ml} \mathrm{min}^{-1}$ ); and (2) the clearance rate was lower (seen as an algal concentration reduction curve between time 140 and $170 \mathrm{~min}$ ) immediately after a period of starvation (between time 80 and $140 \mathrm{~min}$ ).

When the above experiment was repeated, differing only in that either the algal reduction was followed immediately after the first addition of algal cells to the previously starved colonies (Fig. 1b), or the algal cell concentration was followed downwards over time (Fig. 1c: time 80 to $110 \mathrm{~min}$ ), it became obvious that Electra pilosa reacts to low algal concentrations (below a few hundred algal cells $\mathrm{ml}^{-1}$ ) by reducing its feeding activity. The maximum individual zooidal clearance rate was estimated as the colony clearance rate divided by the number of active zooids $=50.1 / 10736=0.28 \mathrm{ml} \mathrm{h}^{-1}$ zooid $^{-1}$

Fig. 2 shows how the number of active zooids (columns depicted in Fig. 2b) varies with feeding conditions. There were no observable active zooids immediately after the starvation period previous to the first algal addition. However, after approximately $1 \mathrm{~h}$ $>90 \%$ of the zooids were feeding (i.e. had their lophophores out). When the algal concentration was allowed to decrease for a period of time (between 200 and $240 \mathrm{~min}$ ) the number of active zooids gradually declined. In spite of the expected uncertainty in the clearance rate measurements due to the short $5 \mathrm{~min}$ time intervals used, it appears (Fig. 2c) as if the clearance rate was constant during periods where the algal concentration was maintained between about 1500 and 3500 cells ml ${ }^{-1}$. However, when the same experiment was repeated, except using higher algal concentrations, between about 3500 and 8000 cells ml $^{-1}$, the clearance rate gradually decreased concomitantly with a conspicuous reduction in the number of active zooids 

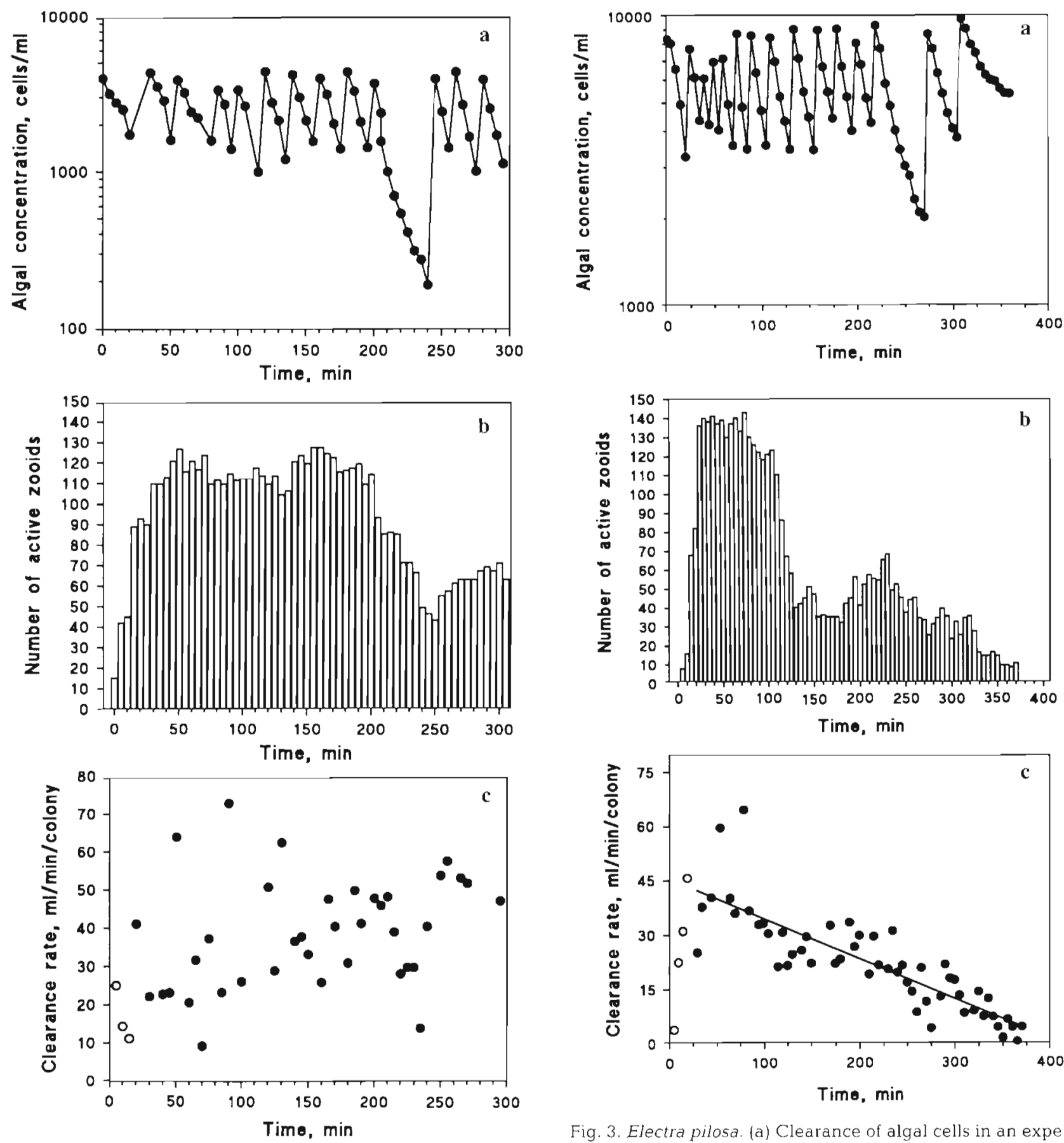

Fig. 2. Electra pilosa. (a) Clearance of algal cells in an experiment with $E$. pilosa in which the algal concentration was maintained between about 1500 and 3500 cells ml $\mathrm{ml}^{-1}$ most of the time. (b) Number of active zooids during the above experiment. (c) Calculated clearance rates during the experiment

(Fig. 3). This shows that Electra pilosa responds to sustained high algal concentrations by withdrawal of the lophophore. Thus, E. pilosa may only continuously exploit its clearance capacity within a certain range of

algal concentrations (equivalent to roughly 400 to 4000 Rhinomonas cells $\mathrm{ml}^{-1}$ ).

The higher variance in clearance rate in Fig. 2c compared with Fig. $3 c$ is not obvious, but may presumably

Fig. 3. Electra pilosa. (a) Clearance of algal cells in an experimont with $E$. pilosa in which the algal concentration was maintained relatively high, between about 3500 and 8000 cells $\mathrm{ml}^{-1}$ (b) Number of active zooids during the above experiment. (c) Calculated clearance rates during the experiment. The regression line has been shown for clearance values calculated for times $>20$ min ( 

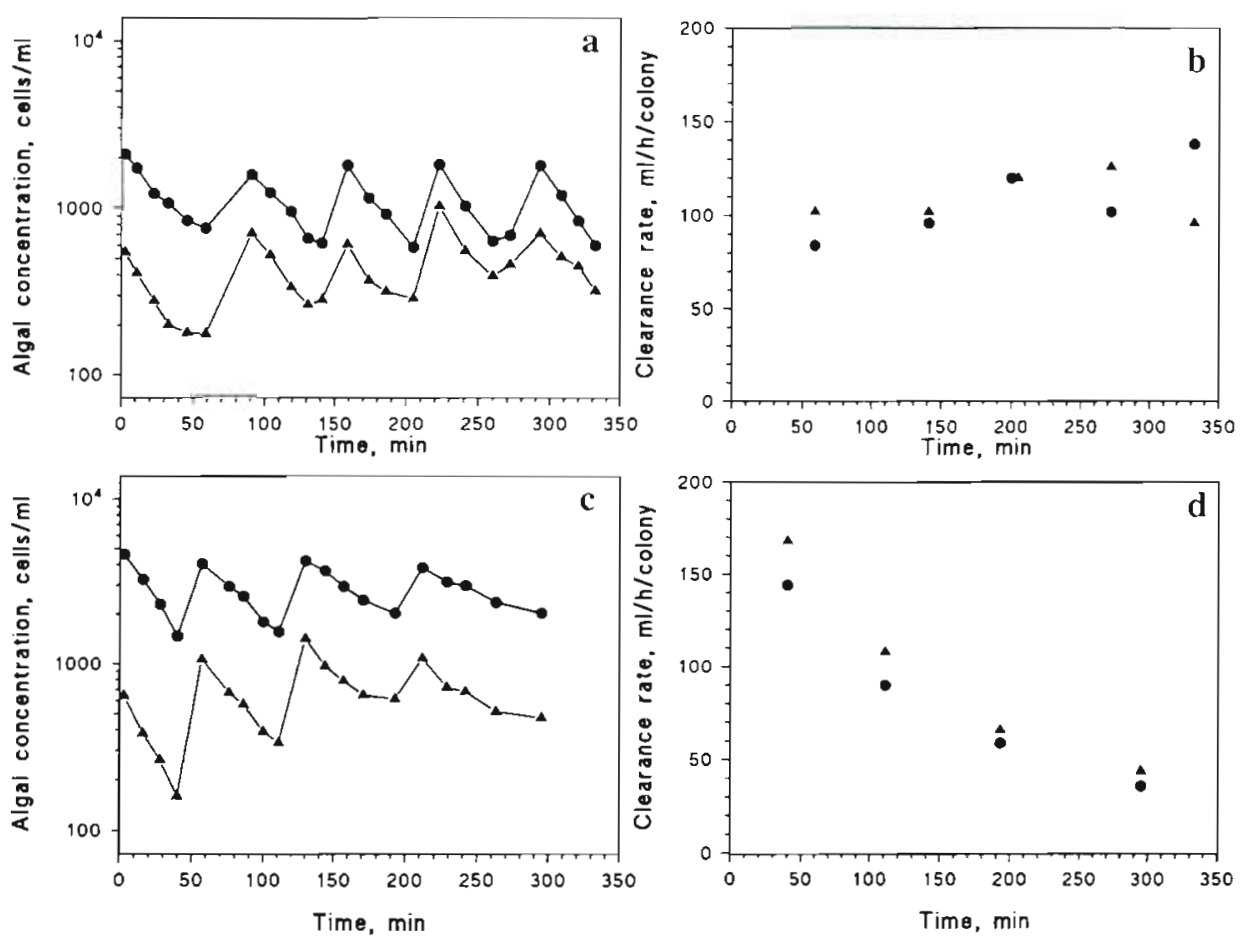

Fiq. 4. Electra crustulenta. Simultaneous clearance of $6 \mu \mathrm{m}$ diameter Rhinomonas ( $\bullet$ ) and $14 \mu \mathrm{m}$ diameter Tetraselmis ( $)$. (a, c) Clearance of algal cells in 2 experiments with $E$. crustulenta in which the algal concentration was maintained relatively constant at 2 levels. (b, d) Calculated clearance rates during the feeding periods. It is noted that the clearance rates of the 2 sizes of algal cells is near identical

be ascribed to a higher accuracy of the electronic particle counting at the higher algal concentration owing to a higher total number of cell counts during the fixed measuring time of $40 \mathrm{~s}$ used in all cases.

\section{Feeding and particle retention in Electra crustulenta}

Figs. 4 \& 5 show simultaneous clearance of 2 different sized algal cells in Electra crustulenta. Fig. 4a shows that Rhinomonas ( $6 \mu \mathrm{m})$ and Tetraselmis $(14 \mu \mathrm{m})$ are cleared from the water at approximately the same rate (i.e. the retention efficiency of E. crustulenta for the 2 algae must be near identical). Moreover, at sustained low algal concentrations the clearance rate is constant (Fig. 4b), whereas the clearance rate gradually declines at raised algal concentrations (Fig. 4c, d). Fig. 5 shows that the clearance of the $6 \mu \mathrm{m}$ diameter Rhinomonas cells is approximately twice that of the smaller Isochrysis (4 $\mathrm{mm}$ ) cells.

\section{Growth}

The growth in colony size of both Celleporella hyalina and Electra pilosa was found to be exponential in all feeding experiments. Examples of exponential growth of 4 colonies, verified as straight regression lines in a semilogarithmic plot, cf. Eq. (4), in different feeding experiments are shown in Fig. 6. The specific growth rates $r$ for colony size (total number of zooids or colony area) as a function of feeding time are shown in Table 1.

The $r$-values in Table 1 were plotted as a function of algal concentration (Fig. 7). Fig. 7 illustrates that the maximum growth rate, obtained at algal concentrations above roughly 4000 cells $\mathrm{ml}^{-1}$, is about $0.10 \mathrm{~d}^{-1}$ in Celleporalla hyalina and approximately $0.11 \mathrm{~d}^{-1}$ in Electra pilosa. Refering to Eq. (5) this corresponds to doubling times of $t_{2}=0.693 / 0.10=7$ and $t_{2}=$ $0.693 / 0.12=6 \mathrm{~d}$, respectively.

The clear morphological differentiation between male, female and feeding zooids in Celleporella hyalina enabled these characters to be monitored (Table 2). Electra pilosa is a protandrous hermaphrodite that does not exhibit somatic and sexual modularity, which led to the exclusion of sexual partitioning in this study. It appears from Table 2 that C. hyalina produces sexual zooids while feeding at high algal concentrations where the growth capacity is exploited (series nos. 3, 4 and 5), but at lower concentrations (series nos. 1 and 2) somatic growth apparently takes precedence. However, an alternative explanation for the latter observation is that the colonies in series no. 1 and 2 were of insufficient size to begin heavily investing in sexual zooids

\section{DISCUSSION}

The present work has demonstrated that the filterfeeding activity in ectoprocts is influenced by the con- 
Fig. 5. Electra crustulenta Simultaneous clearance of $6 \mu \mathrm{m}$ diameter Rhinomonas (•) and $4 \mu \mathrm{m}$ lsochrysis (0). $(a, c)$ Clearance of algal cells in 2 experiments with $E$. crustulenta in which the al. gal concentration was maintained relatively constant at 2 levels. (b, d) Calculated clearance rates during the feeding periods. It is noted that the clearance rate of the larger algal cells is about 2fold higher than that of the smaller algal cells
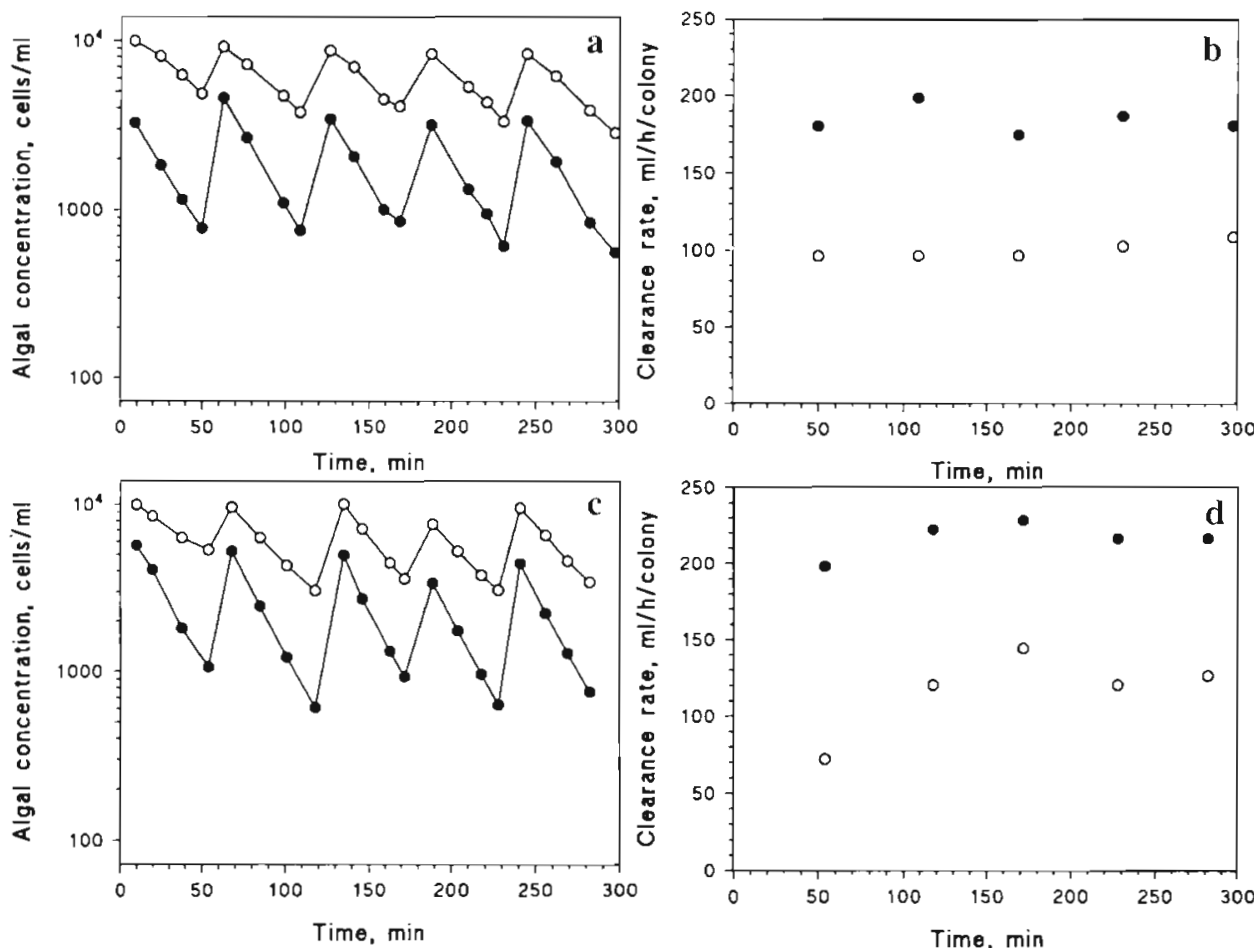

Table 1. Electra pilosa and Celleporella hyalina. Slope of line $\left(r, \mathrm{~d}^{-1}\right)$ and $N_{0}$ for $\ln [$ colony size $(N$, expressed either as total number of zooids or area of colony)l as a function of time ( $t$, days), cf. Eq. (4), in 5 series of feeding experiments with different algal (Rhinomonas) concentrations. Mean \pm SD for the rate of increase in 4 parallel growth experiments with each species is indicated

\begin{tabular}{|c|c|c|c|c|c|c|c|c|}
\hline \multirow[t]{3}{*}{ Series } & \multicolumn{4}{|c|}{ Electra pilosa } & \multicolumn{4}{|c|}{ Celleporella hyalina } \\
\hline & \multicolumn{2}{|c|}{ Number } & \multicolumn{2}{|c|}{ Area } & \multicolumn{2}{|c|}{ Number } & \multicolumn{2}{|c|}{ Area } \\
\hline & $r$ & $N_{0}$ & r & $N_{0}\left(\mathrm{~mm}^{2}\right)$ & $r$ & $N_{0}$ & $r$ & $N_{0}\left(\mathrm{~mm}^{2}\right)$ \\
\hline \multirow[t]{5}{*}{ No. 1} & 0.0134 & 25.6 & 0.0134 & 7.7 & 0.0534 & 16.6 & 0.0534 & 3.6 \\
\hline & 0.0129 & 27.5 & 0.0005 & 7.1 & 0.0771 & 16.4 & 0.0497 & 3.7 \\
\hline & 0.0437 & 21.5 & 0.0099 & 6.7 & 0.0949 & 20.0 & 0.0622 & 4.5 \\
\hline & 0.0373 & 19.9 & 0.0159 & 6.2 & 0.0951 & 16.4 & 0.0488 & 3.9 \\
\hline & \multicolumn{2}{|c|}{$0.0268 \pm 0.0139$} & \multicolumn{2}{|c|}{$0.0099 \pm 0.0059$} & \multicolumn{2}{|c|}{$0.0801 \pm 0.0171$} & \multicolumn{2}{|c|}{$0.0535 \pm 0.0053$} \\
\hline \multirow[t]{5}{*}{ No. 2} & 0.0891 & 23.2 & 0.0956 & 8.5 & 0.0682 & 14.8 & 0.0359 & 3.4 \\
\hline & 0.0919 & 20.7 & 0.0949 & 8.0 & 0.0332 & 15.6 & 0.0203 & 2.9 \\
\hline & 0.0863 & 34.1 & 0.0910 & 12.2 & 0.0801 & 17.0 & 0.0732 & 3.5 \\
\hline & 0.0739 & 17.1 & 0.1087 & 4.9 & 0.0852 & 19.2 & 0.0735 & 4.0 \\
\hline & \multicolumn{2}{|c|}{$0.0853 \pm 0.0069$} & \multicolumn{2}{|c|}{$0.0975 \pm 0.0067$} & \multicolumn{2}{|c|}{$0.0667 \pm 0.0203$} & \multicolumn{2}{|c|}{$0.0507 \pm 0.0233$} \\
\hline \multirow[t]{5}{*}{ No. 3} & 0.1329 & 36.8 & 0.1059 & 15.8 & 0.1236 & 20.1 & 0.1114 & 5.2 \\
\hline & 0.1234 & 32.3 & 0.1027 & 14.3 & 0.1119 & 19.9 & 0.1128 & 4.5 \\
\hline & 0.1119 & 23.3 & 0.0999 & 9.4 & 0.1034 & 16.4 & 0.0882 & 3.9 \\
\hline & 0.1340 & 22.4 & 0.1057 & 11.3 & 0.0852 & 16.6 & 0.0921 & 3.4 \\
\hline & \multicolumn{2}{|c|}{$0.1255 \pm 0.0089$} & \multicolumn{2}{|c|}{$0.1036 \pm 0.0024$} & \multicolumn{2}{|c|}{$0.1060 \pm 0.0140$} & \multicolumn{2}{|c|}{$0.1011 \pm 0.0111$} \\
\hline \multirow[t]{5}{*}{ No. 4} & 0.1091 & 29.6 & 0.1027 & 8.0 & 0.1066 & 32.7 & 0.0866 & 5.8 \\
\hline & 0.1167 & 30.0 & 0.1002 & 8.9 & 0.1179 & 32.4 & 0.0921 & 6.2 \\
\hline & 0.1128 & 30.0 & 0.0907 & 9.5 & 0.1163 & 27.8 & 0.0813 & 5.5 \\
\hline & 0.1048 & 30.2 & 0.0893 & 8.4 & 0.1034 & 34.4 & 0.0748 & 6.5 \\
\hline & \multicolumn{2}{|c|}{$0.1109 \pm 0.0044$} & \multicolumn{2}{|c|}{$0.0957 \pm 0.0058$} & \multicolumn{2}{|c|}{$0.1110 \pm 0.0062$} & \multicolumn{2}{|c|}{$0.0837 \pm 0.0064$} \\
\hline \multirow[t]{5}{*}{ No. 5} & 0.1283 & 31.8 & 0.1009 & 10.5 & 0.0990 & 27.3 & 0.0822 & 4.5 \\
\hline & 0.1402 & 23.4 & 0.1241 & 7.7 & 0.1036 & 28.2 & 0.0829 & 4.6 \\
\hline & 0.1294 & 28.8 & 0.1114 & 8.8 & 0.1055 & 29.5 & 0.0827 & 5.1 \\
\hline & 0.1299 & 30.0 & 0.1096 & 9.5 & 0.1359 & 26.8 & 0.1179 & 4.7 \\
\hline & \multicolumn{2}{|l|}{$0.1319 \pm 0.0048$} & \multicolumn{2}{|c|}{$0.1115 \pm 0.0083$} & \multicolumn{2}{|c|}{$0.1110 \pm 0.0145$} & $0.0914 \pm 0.0$ & \\
\hline
\end{tabular}



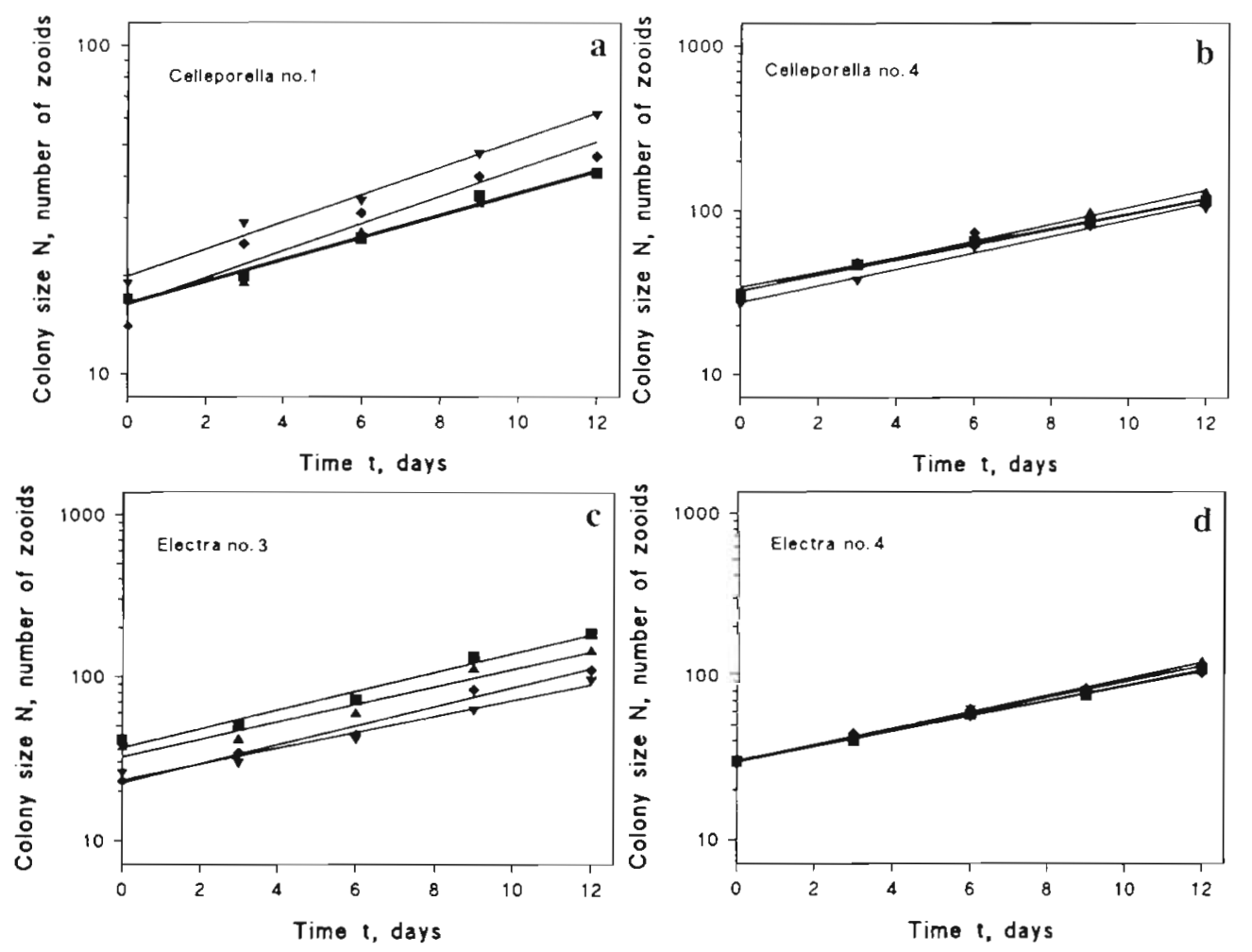

Fig. 6. Celleporella hyalina and Electra piIosa. Examples of exponential growth of 4 small colonies, verified as straight lines in semilogarithmic plot, in different feeding experiments (series nos. 1,3 and 4 )
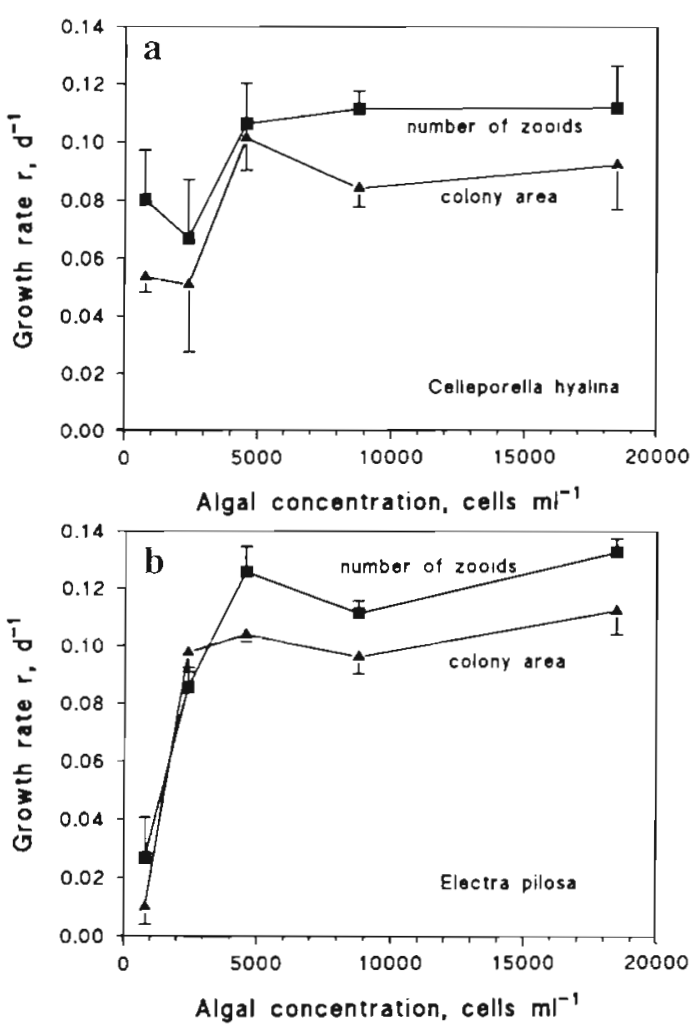

Fig. 7 Celleporella hyalina and Electra pilosa. Specific growth rate ( $r$ ) as a function of algal concentration Error bars denote SD. Data from Table 1

centration of algal cells in the surrounding water (Figs. $1 \&$ 2). Thus, when the algal concentration became very low (corresponding to a few hundred Rhinomonas cells $\mathrm{ml}^{-1}$ ) the colony clearance rate of Electra pilosa was gradually reduced as the number of actively feeding zooids was shutting down (Fig, 1). All zooids were observed to be inactive during a prolonged starvation period, but feeding was quickly resumed after new addition of algal cells (Fig. 2). This closing-down phenomenon has hitherto been overlooked by experimental research workers, but it is in agreement with the recent field observations of the Antarctic flustrids Alloeflustra tenuis and Nematoflustra flagellata which were found to be actively filterfeeding (lophophore index $=96 \%$ or higher) all the time, except for 3 mo in the winter when they shut down in response to extremely low phytoplankton concentrations, $<0.1 \mathrm{\mu g}$ chl a $1^{-1}$ (Barnes \& Clarke 1994). Similar cessation of filter-feeding activity at extremely low algal concentrations (below the 'trigger level') has been revealed in other marine filter-feeding invertebrates such as mussels Mytilus edulis (Riisgård \& Randløv 1981), ascidians Ciona intestinalis (Petersen \& Riisgård 1992), and polychaetes Nereis diversicolor (Vedel et al. 1994).

In the present work it was found that nearly $100 \%$ of the zooids were filter-feeding within a certain range of algal concentrations, roughly between 400 and 4000 Rhinomonas cells $\mathrm{ml}^{-1}$ (Figs. $2 \& 3$ ). Concentrations of 
$4 \times 10^{3}$ Rhinomonas cells $\mathrm{ml}^{-1}$ correspond to $5 \mu \mathrm{g} \mathrm{chl} a \mathrm{l}^{-1}$ which is the median value for Danish fjords and coastal waters between March and October (SandJensen et al. 1994, Clausen \& Riisgård 1996). In the Menai Strait (Wales, UK), Blight et al. (1995) found that the chl a concentrations in 1993 remained low during the summer, near $1 \mu \mathrm{g} \mathrm{l}^{-1}$ (equivalent to 800 Rhinomonas cells $\mathrm{ml}^{-1}$ ). These values may be compared with those measured by Sanderson et al. (1996) in the lower intertidal zone in Port Erin Bay (Isle of Man, Northern Irish Sea). They found that the mean chl a concentration varied over the course of the tidal cycle, ranging from about $16 \mu \mathrm{g} \mathrm{l}^{-1}$ at low tide to approximately $3 \mu \mathrm{g} \mathrm{l}^{-1}$ at high tide (mean $8 \pm 5$ $\mu \mathrm{g} \mathrm{l}^{-1}$ corresponding to 6400 Rhinomonas cells $\mathrm{ml}^{-1}$ ). The above examples of natural phytoplankton concentrations show that ectoprocts presumably never experience such high algal concentrations that they become 'satiated' (cf. Bullivant 1968a) and subsequently shut down, as occurred in the high concentration experiments of the present work (Figs. 3 \& 4).

The normal ectoproct feeding behaviour is characterized by virtually $100 \%$ lophophore activity, steadiness of water pumping, full exploitation of the clearance capacity, and a well-defined frequency of tentacle flickings, dependent on algal concentration. Unnaturally high algal concentrations may lead to violent and disorganized flickings of the tentacles, frequent contractions of the lophophore, expulsions made by the 'pharynx suction-pump', and finally 'satiation' and shutting down of the feeding zooids (Riisgård \& Manríquez 1997). This statement may have consequences for the correct interpretations of earlier experimental work performed at unnaturally high algal concentrations. Thus by way of examples, Best \& Thorpe (1983, 1986), Hunter \& Hughes (1993), Sanderson \& Thorpe (1996), Sanderson et al. (1994), and Bayer \& Todd (1996) performed laboratory experiments at very high algal concentrations (up to $2 \times 10^{5}$ algal cells $\mathrm{ml}^{-1}$ ).

The laboratory-created phenomenon of 'satiation' at unnaturally high algal concentrations, gradually leading to reduced clearance rates, is well known in other marine suspension-feeding invertebrates (e.g. Riisgård \& Ivarson 1990, Riisgård 1991, Petersen \& Riisgård 1992, Clausen \& Riisgård 1996), but should not be interpreted as physiological regulation of the filterpumps. This stresses the importance, in particular when studying feeding behaviour, of performing laboratory experiments under optimal conditions, including natural algal concentrations at which the pumping capacity is exploited, as earlier emphasized by Riisgărd \& Larsen (1995).

The present growth experiments (Fig. 7) show that the growth potential under the given conditions may be fully utilized at about 4000 Rhinomonas cells $\mathrm{ml}^{-1}$. Based on our own and previous values (Riisgård \& Manriquez 1997) estimation of the Rhinomonas algal concentration necessary to cover the energy requirement in Celleporella hyalina is about 180 cells $\mathrm{ml}^{-1}$ (or $0.2 \mu \mathrm{g} \mathrm{chl} \mathrm{a} \mathrm{l}^{-1}$ ). Referring to these figures it may be expected that the growth rate of ectoprocts may be directly proportional to the algal concentration in the range of about 200 to 4000 Rhinomonas cells $\mathrm{ml}^{-1}$, above which no further increase in growth rate may be obtained. This statement is in fairly good agreement with the findings of present work (Fig. 7). We found that the growth rate was almost constant, about 10 to 
$12 \% \mathrm{~d}^{-1}$, above 4000 and up to 18000 cells $\mathrm{ml}^{-1}$ (Fig. 7). However, reduced growth may be expected if the algal concentration is further increased (due to interruption of the feeding process and shutting down of the zooids). Thus, the growth rate measured by Hunter \& Hughes (1993) in C. hyalina fed a concentration of $10^{5}$ Rhinomonas cells $\mathrm{ml}^{-1}$ every third day over a $49 \mathrm{~d}$ period was lower than that found in the present work: during the growth period the initial 10 autozooids increased to 249 which, referring to Eq. (6), gives an estimated specific growth rate of $r=\ln (249 / 10) / 49=0.066$ $\mathrm{d}^{-1}\left(t_{2}=11 \mathrm{~d}\right)$. However, Bayer et al. (1994) did not observe reduced growth in Electra pilosa at high algal concentrations. Recalculated maximum ectoproct specific growth rates obtained in both laboratory and field growth experiments are listed in Table 3 . It is apparent that maximum growth rates vary between different species and investigators. In general, most investigators have used much higher algal concentrations than required for maximum growth. Further, it is striking that a doubling time of only $2 \mathrm{~d}$ may be the maximum obtainable in ectoprocts. This calls attention to the need for further examination of aptimal conditions for laboratory growth (and keeping) of ectoprocts.
The low retention efficiency of Electra crustulenta for the $4 \mu \mathrm{m}$ algal cells (Isochrysis) as compared with the $6 \mu \mathrm{m}$ (Rhinomonas) and $14 \mu \mathrm{m}$ cells (Tetraselmis) in the present work (Figs. 4 \& 5) supports the retentionefficiency spectrum recently determined for Celleporella hyalina (Riisgărd \& Manriquez 1997). This shows that the distance between neighbouring laterofrontal cilia, making up the laterofrontal filter on the lophophore tentacles, may be about 5 to $6 \mu \mathrm{m}$ in both species.

The maximum individual zooidal clearance rate $(F=$ volume of water cleared for particles $>6 \mu \mathrm{m}$ per unit of time by the laterofrontal filter) of Electra pilosa was found to be $0.28 \mathrm{ml} \mathrm{h}^{-1}$ This is in good agreement with clearance rates reported by Menon (1974). Recently, Riisgård \& Manriquez (1997) measured the pumping rate $(Q=$ total volume of water pumped through the lophophore entrance) of E. pilosa to be $1.09 \mathrm{ml} \mathrm{h}^{-1}$ zooid $^{-1}$ The ratio $F / Q=0.28 / 1.09=0.26$ shows that only about $25 \%$ of the total volume of water pumped by the lophophore is passing through the laterofrontal filter on the tentacles while the remaining water may bypass the tentacles in the outer part of the lophophore.

Table 3. Maximum colony growth rates obtained in laboratory and field growth experiments with ectoprocts fed different concentration of algal cells. $r$ : specific growth rate; $t_{2}$ : doubling time. Note: Rhinomonas reticulata $=$ Rhodomonas baltica

\begin{tabular}{|c|c|c|c|c|c|}
\hline Species & $\begin{array}{l}\text { Algal concentration } \\
\left(\times 10^{3} \text { cells } \mathrm{ml}^{-1}\right)\end{array}$ & Algal species & $\begin{array}{c}r \\
\left(d^{-1}\right)\end{array}$ & $\begin{array}{c}t_{2} \\
\text { (d) }\end{array}$ & Source \\
\hline \multirow[t]{5}{*}{ Electra pilosa } & 0.1 & Rhodomonas sp. & 0.02 & 35 & Bayer et al. $(1994)^{d}$ \\
\hline & 1 & Rhodomonas sp. & 0.09 & 8 & Bayer et al. $(1994)^{d}$ \\
\hline & 10 & Rhodomonas sp. & 0.3 & 2 & Bayer et al. $(1994)^{a}$ \\
\hline & 100 & Rhodomonas sp. & 0.3 & 2 & Bayer et al. $(1994)^{d}$ \\
\hline & 43 & Rhodomonas sp. & 0.05 & 13 & Bayer \& Todd $(1996)^{b}$ \\
\hline Electra pilosa & 4 & Rhinomonas reticulata & 0.12 & 6 & Present work \\
\hline Conopeum tenulssimum & 177 & Dunaliella $\mathrm{sp}$. & 0.25 & 3 & Winston $(1976)^{r}$ \\
\hline Conopeum seurati & '>Satiation conc.' & Oxyrrhis marina & 0.37 & 2 & Jebram \& Rummert (1978) d \\
\hline Celleporella hyalina & 100 & Rhodomonas baltica & 0.07 & 11 & Hunter \& Hughes $(1993)^{e}$ \\
\hline Celleporella hyalina & 4 & Rhodomonas baltica & 0.10 & 7 & Present work \\
\hline Valdemunitella valdemunita & Field & & 0.11 & 6 & Wass \& Vail $(1978)^{r}$ \\
\hline Bugula neritina & Field & & 0.43 & 2 & Kitamura \& Hirayma $(1984)^{\mathrm{g}}$ \\
\hline \multicolumn{6}{|c|}{ ${ }^{2}$ Maximum values read from Fig. 2 and transformed to $r$ according to Eq. (6) } \\
\hline \multicolumn{6}{|c|}{ Maximum value read from Fig. 3; calculation based on $103 \mathrm{~d}$ of growth } \\
\hline \multicolumn{6}{|c|}{ "Calculation based on regression analysis on values for the first $20 \mathrm{~d}$, read from Fig. $2 \mathrm{~A}$} \\
\hline \multicolumn{6}{|c|}{ dValues for the first 19 d, read from Fig. 1} \\
\hline \multicolumn{6}{|c|}{ EValue given in Table 1} \\
\hline \multicolumn{6}{|c|}{ 'Calculation based on first $21 \mathrm{~d}$, values for colony no. 1 in Table 1} \\
\hline
\end{tabular}




\section{CONCLUSION}

In the presence of algal cells in the concentration interval between a lower 'trigger level' and an upper 'satiation level' filter-feeding ectoprocts continuously utilize their clearance capacity. Observations of the feeding activity have revealed that alterations in colony clearance rates as a response to either extremely low or unnaturally high algal concentrations are caused by a shutting down of the number of actively feeding zooids. The lowest algal concentration that causes maximum growth rate of ectoprocts is virtually identical to the mean summer phytoplankton levels in fjords and coastal waters, and this implies that ectoprocts in nature, as a rule, always utilize their clearance capacity (i.e. no physiological regulation of the filter-pump takes place).

Acknowledgements. H.U.R was supported by a grant from the Danish Natural Research Council (reg. no. 28-808) during his sabbatical stay at the School of Biological Sciences, University of Wales (UWB). A.G. was funded by a grant held by Prof Roger Hughes (UWB) who strongly supported the work and passed remarks on the manuscript. Thanks are due to Pernille O. Hermansen for placing some of her data (bachelor project supervised by H.U.R.) on Electra crustulenta at our disposal.

\section{LITERATURE CITED}

Barnes DKA, Clarke A (1994) Season variation in the feeding activity of four species of Antarctic bryozoan in relation to environmental factors. J Exp Mar Biol Ecol 181:117-133

Bayer MM, Cormack RM, Todd CD (1994) Influence of food concentration on polypide regression in the marine bryozoan Electra pilosa (L.) (Bryozoa, Cheilostomata). J Exp Mar Biol Ecol 178:35-50

Bayer MM, Todd CD (1996) Effect of polypide regression and other parameters on colony growth in the cheilostomate Electra pilosa (L.). In: Gordon DP, Smith AM, GrantMackie JA (eds) Bryozoans in space and time. Proceedings of the 10th international bryozoology conference, Wellington, New Zealand, 1995. National Institute of Water and Atmospheric Research, Wellington, p 29-38

Bayne BL, Hawkins AJS, Navarro E (1987) Feeding and digestion by the mussel Mytnlus edulus L. (Bivalvia: Mollusca) in mixtures of silt and algal cells at low concentrations. J Exp Mar Biol Ecol 111:1-22

Bayne BL, Hawkins AJS, Navarro E (1988) Feeding and digestion in suspension-feeding bivalve molluscs: the relevance of physiological compensations. Am Zool 28: $147-154$

Bayne BL, Hawkins AJS, Navarro E, Iglesias JIP (1989) Effects of seston concentration on feeding, digestion and growth in the mussel Mytilus edulis. Mar Ecol Prog Ser 55:47-54

Best MA, Thorpe JP (1983) Effects of particle concentration on clearance rate and feeding current velocity in the marine bryozoan Flustrellidra hispida. Mar Biol 77:85-92

Best MA, Thorpe JP (1986) Effects of food particle concentration on feeding current velocity in six species of marine Bryozoa. Mar Biol 93:255-262

Best MA, Thorpe J (1994) Particle size, clearance rate and feeding efficiency in marina Bryozoa. In: Hayward PJ, Ryland JS, Taylor PD (eds) Biology and palaeobiology of bryozoans. Proceedings of the 9th international bryozoology conference. University of Wales, Swansea, 1992. Olsen \& Olsen, Fredensborg, p 9-14

Best MA. Thorpe JP (1996) Effect of suspended particulate matter (silt) on feeding activity of the intertidal ctenostomate bryozoan Flustrellidra hispida (Fabricius). In: Gordon DP, Smith AM, Grant-Mackie JA (eds) Bryozoans in space and time. Proceedings of the 10 th international bryozoology conference, Wellington, New Zealand, 1995. National Institute of Water and Atmospheric Research, Wellington, p $39-45$

Blight ST, Bently IT, Lefevre D, Robinson C, Rodnigues R, Rowlands J, Williams PJleB (1995) Phasing of autrotrophic and heterotrophic plankton metabolism in a temperate coastal ecosystem. Mar Ecol Prog Ser 128:61-75

Bullivant JS (1968a) The rate of feeding of the bryozoan. Zoobotryon verticillatum. NZ J Mar Freshwat Res 2: 111-134

Bullivant JS (1968b) The method of feeding of lophophorates (Bryozoa, Phoromda, Brachiopoda). NZ J Mar Freshwat Res 2:135-146

Clausen I, Riisgård HU (1996) Growth, filtration and respiration in the mussel Mytilus edulis: no regulation of the filter-pump to nutritional needs. Mar Ecol Prog Ser 141. $37-45$

Gordon DP, Clark AG, Harper JF (1987) Bryozoa. In: Animal energetics, Vol 2. Academic Press, London, p 173-199

Hawkins AJS, Bayne BL (1992) Physiological interrelations, and the regulation of production. In: Gosling $E$ (ed) The mussel Mytilus: ecology, physiology, genetics and culture. Elsevier, Amsterdam, p 171-222

Hayward PJ, Ryland JS (1995) Handbook of the marine fauna of North-West Europe. Oxford University Press, Oxford

Hunter E, Hughes RN (1993) The effect of cell concentration on colony growth and feeding in the bryozoan Celleporella hyalina. J Mar Biol Assoc UK 73:321-331

Hunter E, Hughes RN (1995) Environmental and genetic components of variation in sexual allocation by an epialgal bryozoan. Mar Ecol Prog Ser 120:193-201

Jebram D, Rummert HD (1978) Influences of different diets on growth and forms of Conopeum seurati (CANU)(Bryozoa, Cheilostomata). Zool Jahrb Abt Syst Oekol Geogr Tiere 105:502-514

Jørgensen CB (1975) Comparative physiology of suspension feeding. Annu Rev Physiol 37:57-79

Jorgensen CB (1990) Bivalve filter-feeding: hydrodynamics, bioenergetics, physiology and ecology. Olsen \& Olsen, Fredensborg

Jørgensen CB (1996) Bivalve filter feeding revisited. Mar Ecol Prog Ser 142:287-302

Kitamura H, Hirayama K (1984) Growth of the bryozoan Bugula nertina in the sea at various water temperatures. Bull Jap Soc Scient Fish 50:1-5

McKinney FK (1990) Feeding and associated colonial morphology in marine bryozoans. Rev Aquat Sci 2:255-288

Menon NR (1974) Clearance rates of food suspension and food passage rates as a function of temperature in two North Sea bryozoans. Mar Biol 24:65-67

Nielsen $C(1987)$ Structure and function of metazoan ciliary bands and their phylogenetic significance. Acta Zool Stockh 68:202-262

Nielsen C (1995) Animal evolution. Interrelationships of living phyla. Oxford University Press, Oxford

Novarino G (1992) Observations on Rhinomonas reticulata comb. nov. and and $R$. reticulata var. eleniana var. nov. 
(Cryptophyceae), with comments on the genera Pyrenomonas and Rhodomonas. Nord J Bot 11:243-252

Okamura B (1992) Microhabitat variation and patterns of colony growth and feeding in a marine bryozoan. Ecology 73:1502-1513

Petersen JK, Riisgård HU (1992) Filtration capacity of the ascidian Ciona intestinalis and its grazing impact in a shallow fjord. Mar Ecol Prog Ser 88:9-17

Riisgård HU (1991) Filtration rate and growth in the blue mussel, Mytilus edulis Linnaeus, 1758: dependence on algal concentration. J Shellfish Res 10:29-35

Riisgård HU, Ivarson NM (1990) The crown-filament pump of the suspension-feeding polychaete Sabella penicillus: filtration, effects of temperature, and energy cost. Mar Ecol Prog Ser 62:249-257

Riisgård HU, Larsen PS (1995) Filter-feeding in marine macroinvertebrates: pump characteristics, modelling and energy cost. Biol Rev Cambridge Phil Soc 70:67-106

Riisgård HU, Manríquez P (1997) Filter-feeding in fifteen marine ectoprocts (Bryozoa): particle capture and water pumping. Mar Ecol Prog Ser 154:223-239

Riisgård HU, Randløv A (1981) Energy budgets, growth and filtration rates in Mytilus edulis at ditterent algal concentrations. Mar Biol 61:227-234

Ryland JS (1976) Physiology and ecology of marine bryozoans. Adv Mar Biol 14:285-443

Sanderson WG, Harding SP, Thorpe JP (1996) An investigation of the effects of tidal fluctuations on the availability of seston as food for intertidal Bryozoa. In: Gordon DP, Smith AM, Grant-Mackie JA (eds) Bryozoans in space and time. Proceedings of the 10th international bryozoology conference, Wellington, New Zealand, 1995. National Institute of Water and Atmospheric Research, Wellington, p 259-269

This article was submitted to the editor
Sanderson WG, Thorpe JP (1996) Effects of temperature on the feeding activity of some temperate intertidal bryozoa. In: Gordon DP, Smith AM, Grant-Mackie JA (eds) Bryozoans in space and time. Proceedings of the 10 th international bryozoology conference, Wellington, New Zealand, 1995. National Institute of Water and Atmospheric Research, Wellington, p 271-281

Sanderson WG, Thorpe JP, Clarke A (1994) A preliminary study of feeding rates in the Antarctic cheilostomate bryozoan Himantozoum antarctium. In: Hayward PJ, Ryland JS, Taylor PD (eds) Biology and palaeobiology of bryozoans. Proceedings of the 9th international bryozoology conference. University of Wales, Swansea, 1992. Olsen \& Olsen, Fredensborg, p 167-171

Sand-Jensen $K$, Nielsen SL, Borum J, Geertz-Hansen $O$ (1994) Fytoplankton- og makrofytudviklingen i danske kystområder ('Phytoplankton and macrophyte development in Danish coastal waters'). Havforskning fra Miljostyrelsen no. 30 (in Danish with English summary)

Sprung M (1995) Physiological energetics of the zebra mussel Dreissena polymorpha in lakes II. Food uptake and gross growth efficiency. Hydrobiologia 304:133-146

Vedel A, Andersen BB, Riisgård HU (1994) Field investigations of pumping activity of the facultatively filter-feeding polychaete Nereis diversicolor using an improved infrared phototransducer system. Mar Ecol Prog Ser 103:91-101

Wass RE, Vail LL (1978) Encrusting bryozoa exhibit linear growth. Search 9:42-43

Willows RI (1992) Optimal digestive investment: a model for filter feeders experiencing variable diets. Limnol Oceanogr 37:829-847

Winston J (1976) Experimental culture of the estuarine ectoproct Conopeum tenuissimum from Chesapeake Bay. Biol Bull Mar Biol Lab Woods Hole 150:318-335

Manuscript received: May 5, 1997

Revised version accepted: July 22, 1997 